\title{
Derived Placental Blood Cell
}

National Cancer Institute

\section{Source}

National Cancer Institute. Derived Placental Blood Cell. NCI Thesaurus. Code C133262.

Cells collected from placental blood. 